\title{
Uji berbagai Sistem Tanam terhadap Pertumbuhan dan Produktivitas Tanaman Padi (Oryza sativa L.)
}

\author{
Makmur $^{1}$, Harli A. Karim² ${ }^{2}$ Hasanuddin $\mathrm{K}^{3}$, Suryadi ${ }^{4}$ \\ ${ }^{1}$ Program Studi Agribisnis Fakultas Pertanian dan Kehutanan Universitas Sulawesi Barat \\ ${ }^{2,3,4}$ Program Studi Agroteknologi Fakultas Ilmu Pertanian Universitas Al Asyariah Mandar
}

Correspondence Author : harlipertanian@gmail.com

\begin{abstract}
Abstrak
Tanaman padi merupakan tanaman penting dan strategis di Indonesia. Kebutuhan pangan khususnya beras mengalami peningkatan setiap tahunnya. Salah satu unsur iklim yang sangat mempengaruhi pertumbuhan dan produksi padi adalah curah hujan. Produktivitas rata-rata tanaman padi berkisar 5,14 t/ha. Padahal, potensi produktivitas tanaman padi dapat mencapai 10-11 t/ha. Salah satu penyebabkan rendahnya produktivitas tersebut adalah sistem tanam yang belum tepat. Upaya yang bisa diakukan untuk mengatasi permasalahan tersebut adalah dengan menguji berbagai sistem tanam yang sering digunakan petan. Penelitian ini bertujuan untuk menguji berbagai sistem tanam ( SRI, Jajar Legowo 2:1, Hazton, Tegel, Tabela dan Hambur) terhadap pertumbuhan dan produktivitas tanaman padi. Penelitian ini dilaksanakan di Desa Nepo Kecamatan Wonomulyo Kabupaten Polewali Mandar selama \pm 4 bulan dimulai dari Mei-Juli 2020 dengan menggunakan Rancangan Acak Kelompok yang terdiri dari faktor sistem tanam dengan 6 perlakuan yaitu System Rice Intensification (SRI), Legowo 2:1, Hazton, Tegel, Tanam Benih Langsung dan Hambur. Masing-masing perlakuan diulang sebanyak 3 kali, sehingga ada 18 petak penelitian. Analisis statistik dilakukan dengan uji F pada taraf nyata $5 \%$. Jika F hitung lebih besar dari F tabel $5 \%$, maka dilanjutkan dengan uji Duncan's New Multiple Range Test (DNMRT). Pengamatan dilakukan terhadap tinggi tanaman, jumlah anakan vegetatif dan produktif, jumlah gabah isi tiap malai, Panjang malai, jumlah gabah permalai, berat gabah 1000 biji, hasil perpetak dan Hasil per hektar. Hasil penelitian menunjukkan bahwa sistem tanam tabela menunjukkan rata-rata tinggi tanaman terbaik pada umur 45 HST dan 60 HST. Padi yang ditanam menggunakan legowo menghasilkan produktivitas 13.07 ton/ha. Hasil tersebut merupakan hasil tertinggi diabandingkan dengan sistem tanaman lainnya yaitu tegel (12.60 ton/ha), hazton (12.08 ton/ha), sistem SRI (11.67 ton/ha), tabela (9.91ton/ha) dan hambur (8.56 ton/ha).
\end{abstract}

Kata kunci : uji, sistem tanam, produktivitas, padi

\section{Pendahuluan}

Tanaman padi (Oryza sativa L.) merupakan komoditas tanaman pangan utama di Indonesia karena sebagian besar penduduk Indonesia makanan pokoknya adalah beras. Permintaan akan beras terus meningkat seiring bertambahnya jumlah penduduk, dan terjadinya perubahan pola makanan pokok pada beberapa daerah tertentu, dari umbi-umbian ke beras.

Salah satu penyebab rendahnya produksi padi di Indonesia karena umumnya petani masih membudidayakan padi tidak secara tidak tepat, seperti pengolahan tanah, sistem tanam dan pemupukan yang tidak sesuai dengan rekomendasi yang di anjurkan.

Budidaya padi secara umum dilakukan dengan tujuan mendapatkan produksi dan kualitas sebaik mungkin dengan mengoptimalkan serta mengefisienkan sumberdaya yang tersedia. Banyak upaya telah dilakukan untuk mengembangkan varietas tanaman yang mempunyai produktifitas tinggi dan beberapa keunggulan komparatif lainnya serta beberapa bentuk teknologi budidaya padi yang telah dilakukan antara lain teknologi budidaya System of Rice Intensification ( SRI ), Hazton, Jajar Legowo (Legowo) dan lain-lain. Pengenalan dan penggunaan sistem tanam tersebut disamping untuk mendapatkan pertumbuhan tanaman yang optimal juga ditujukan untuk meningkatkan hasil dan pendapatan petani.
Dengan adanya teknologi ini, diharapkan petani mampu mengevaluasi kegiatan-kegiatan usaha tani yang telah dijalaninya, mulai dari aspek produksi padi/produktivitas lahan, penggunaan pupuk organik setiap musim tanam baik jumlah maupun jenisnya, pemakaian pestisida di lahan usaha tani, jenis dan tingkat serangan Organisme Pengganggu Tanaman (OPT), kondisi air sampai dengan biaya usaha tani. Selain mendapatkan hasil produksi yang melimpah, kualitas tetap harus terjaga sehingga petani memiliki posisi daya tawar yang baik dipasaran sehingga diperoleh keuntungan yang lebih baik.

Berdasarkan hal tersebut maka perlu dilakukan penelitian yang bertujuan untuk membandingkan beberapa sistem tanam terhadap pertumbuhan dan produksi tanaman padi dengan judul Uji Sistem Tanam terhadap Pertumbuhan dan berbagai Produktivitas Tanaman Padi (Oryza sativa L.) di Lahan Sawah.

\section{Metodologi}

Rancangan yang digunakan dalam penelitian adalah Rancangan Acak Kelompok yang terdiri dari faktor sistem tanam dengan 6 perlakuan sebagai berikut :

1. System of Rice Intensification $(\mathrm{SRI})=\mathrm{SRI}$

2. Jajar Legowo $2: 1=\mathrm{Lg}$

3. Hazton $=\mathrm{Hz}$

4. Tegel $=\mathrm{Tg}$

5. Tanam benih langsung (Tabela) $\quad=\mathrm{Tb}$

6. Hambur = $\mathrm{Hb}$ 
masing-masing perlakuan diulang sebanyak 3 kali, sehingga ada 18 petak penelitian. Analisis statistik dilakukan dengan uji $\mathrm{F}$ pada taraf nyata $5 \%$. Jika $\mathrm{F}$ hitung lebih besar dari $\mathrm{F}$ tabel $5 \%$, maka dilanjutkan dengan Duncan's New Multiple Range Test (DNMRT).

\section{Hasil}

\section{Komponen Pertumbuhan Tanaman Padi}

\section{Tinggi Tanaman}

Tabel 1. Rata-Rata Tinggi Tanaman Padi $(\mathrm{cm})$ Pada Berbagai Umur Pengamatan.

\begin{tabular}{|c|c|c|c|c|}
\hline \multirow{2}{*}{ Kode } & \multirow{2}{*}{ Perlakuan } & \multicolumn{3}{|c|}{ Tinggi Tanaman (Cm) } \\
\hline & & $30 \mathrm{HST}$ & $45 \mathrm{HST}$ & $60 \mathrm{HST}$ \\
\hline SRI & $\begin{array}{l}\text { System Rice } \\
\text { Intensification }\end{array}$ & $75.55 \mathrm{a}$ & $95.00 \mathrm{ab}$ & $118.66 \mathrm{bc}$ \\
\hline $\mathrm{Hz}$ & Hazton & $86.78 \mathrm{a}$ & $102.56 \mathrm{~b}$ & $110.00 a b$ \\
\hline $\operatorname{Tg}$ & Tegel & $78.78 \mathrm{a}$ & $88.67 \mathrm{a}$ & $106.67 \mathrm{a}$ \\
\hline $\mathrm{Hb}$ & Hambur & $84.56 \mathrm{a}$ & $102.89 \mathrm{~b}$ & $116.00 \mathrm{abc}$ \\
\hline $\mathrm{Tb}$ & Tabela & 85.89 a & $103.55 \mathrm{~b}$ & $124.78 \mathrm{c}$ \\
\hline $\operatorname{Lg}$ & Legowo & $81.78 \mathrm{a}$ & $90.11 \mathrm{a}$ & 107.33 a \\
\hline KK & & 0.34 & 0.49 & 0.46 \\
\hline
\end{tabular}

Pada Tabel 1 menunjukkan umur 30 dan 45 HST, sistem tanam tabela, hambur dan hazton menunjukan tinggi tanaman tertinggi, hal tersebut dikarenakan ketiga sistem tanam tersebut tidak menyebabkan bibit padi pada lahan sawah tidak mengalami stres, dimana tabela, benih yang telah direndam langsung ditanam pada petak sawah, sistem tanam hambur, benih yang telah direndam disebar pada sawah, sedangkan hazton benih dipindahkan setelah berumur 30-35 hari sehingga tanaman cepat beradaptasi dan tidak stres. Memasuki umur 60 HST tinggi tanaman untuk hazton dilampaui oleh SRI, hal tersebut disebabkan karena pada sistem tanam hazton bibit ditanam 20-30 per lubang yang menyebabkan terjadinya persaingan, baik pada unsur hara, cahaya serta ruang tumbuh sehingga pertumbuhan tidak maksimal.

Sistem tanam Legowo dan Tegel yang dipindahkan setelah bibit berumur 18-20 hari memiliki tinggi tanaman yang lebih rendah pada umur 30 dan 45 HST yang tidak berbeda nyata dengan SRI, dimana bibit dipindahkan setelah berumur 8 hari, namun pada umur 60 HST SRI menunjukkan tinggi tanaman yang berbeda nyata dengan Legowo dan Tegel. Semakin cepat bibit pindah lapang akan semakin memadai periode bibit beradaptasi dengan lingkungan baru, sehingga semakin memadai periode untuk perkembangan anakan dan akar (Usman, Made, Adrianton, 2014).

\section{Jumlah Anakan}

Tabel 2. Rata-rata jumlah anakan padi (batang) pada berbagai umur pengamatan.

\begin{tabular}{|c|c|c|c|c|c|}
\hline \multirow[b]{2}{*}{ Kode } & \multirow[b]{2}{*}{ Perlakuan } & \multicolumn{4}{|c|}{ Jumlah Anakan } \\
\hline & & $30 \mathrm{HST}$ & $45 \mathrm{HST}$ & $60 \mathrm{HST}$ & $\begin{array}{l}\text { Produktif } \\
\text { (batang) }\end{array}$ \\
\hline SRI & $\begin{array}{l}\text { System Rice } \\
\text { Intensification }\end{array}$ & $29.00 \mathrm{~b}$ & $30.67 b$ & $26.33 \mathrm{c}$ & $21.00 \mathrm{c}$ \\
\hline $\mathrm{Hz}$ & Hazton & $13.33 \mathrm{a}$ & $11.67 \mathrm{a}$ & $4.00 \mathrm{a}$ & $0.67 \mathrm{a}$ \\
\hline $\mathrm{Tg}$ & Tegel & $32.33 b$ & $25.00 \mathrm{~b}$ & $24.00 \mathrm{bc}$ & $23.00 \mathrm{C}$ \\
\hline $\mathrm{Hb}$ & Hambur & $31.33 b$ & $26.00 \mathrm{~b}$ & $17.00 \mathrm{~b}$ & $12.67 \mathrm{~b}$ \\
\hline $\mathrm{Tb}$ & Tabela & $45.33 \mathrm{c}$ & $31.33 b$ & $26.00 \mathrm{c}$ & $22.67 \mathrm{c}$ \\
\hline $\operatorname{Lg}$ & Legowo & $26.33 \mathrm{~b}$ & $26.00 \mathrm{~b}$ & $23.00 \mathrm{bc}$ & $18.33 \mathrm{bc}$ \\
\hline KK & & 1.34 & 1.00 & 1.35 & 1.50 \\
\hline
\end{tabular}

Keterangan: Angka-angka yang diikuti oleh huruf yang sama pada kolom yang sama menunjukkan berbeda tidak nyata pada uji Duncan taraf $5 \%$

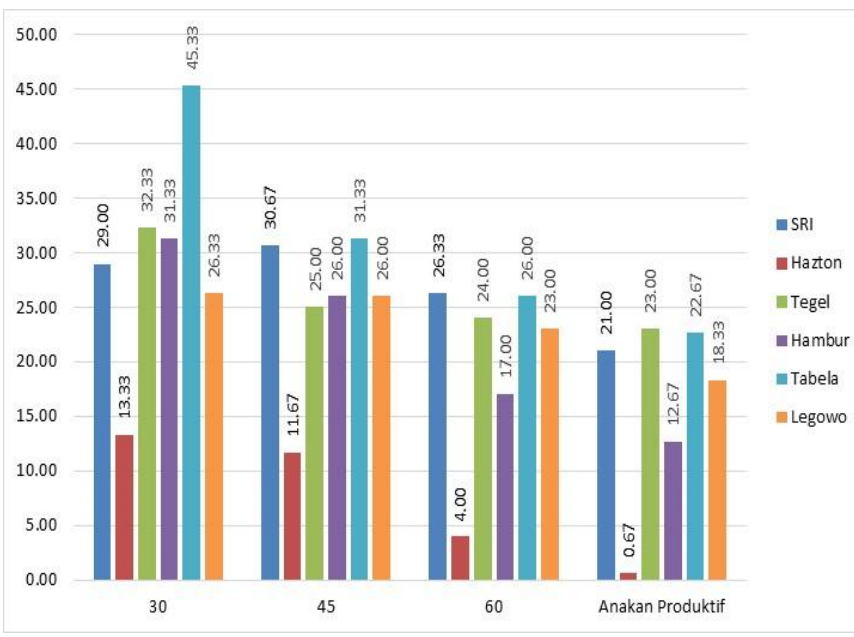

Gambar 3. Grafik pertumbuhan jumlah anakan pada pengamatan 30, 45 dan 60 HST dan anakan produktif.

Tabel 2 dan Gambar 3. menunjukkan jumlah anakan paling rendah yaitu Hazton pada semua umur pengamatan hal tersebut disebabkan, Hazton menggunakan bibit tua (3035 hari) ditanam 30 batang per lubang yang diharapkan menjadi indukan produktif yang cenderung tidak menghasilkan anakan, sehingga akan lebih produktif. Jadi yang perlu dipahami bahwa Hazton tidak menghasilkan anakan produktif, melainkan indukan produktif, berbeda dengan sistem tanam SRI, Tabela, Tegel, Legowo dan Hambur yang menitik beratkan pada jumlah anakan produktif untuk menghaslkan produksi yang lebih tinggi.

Pada Gambar 3. menunjukkan tanaman mencapai titik maksimum jumlah anakan pada pengamatan 45 HST dan mengalami pengurangan jumlah anakan pada $60 \mathrm{HST}$, dikarenakan jumlah anakan produktif mengalami pengurangan jika dibandingkan dengan jumlah anakan per rumpun, disebabkan adanya anakan yang mati dan tidak produktif, hal itu dikarenakan persaingan sesamanya untuk mendaptkan unsur hara, cahaya dan air yang dibutuhkan, selain itu tanaman akan memasuki fase generatif yang 
mengakibatkan pertumbuhan anakan tanaman terhenti sehingga fotosintat yang dihasilkannya tidak lagi digunakan untuk perkembangan dan pertambahan tinggi batang, namun dialihkan keperkembangan dan pengisian bulir padi (fase generatif) (Lestari, 2012). Ini sesuai dengan hasil penelitian Ridwan (2000) bahwa jumlah anakan produktif tanaman dipengaruhi oleh jumlah anakan per rumpunnya, semakin banyak jumlah anakannya, maka jumlah anakan produktifnya juga semakin banyak.

Pemindahan bibit secara konvensional dari persemaian umumnya berumur 20-30 hari dengan 5-7 bibit perlubang tanaman bahkan lebih. Umur bibit yang lama sebelum dipindahkan ke lahan menyebabkan bibit telah menghasilkan anakan ketika masih dipersemaian sehingga ketika bibit dicabut maka pertumbuhan anakan akan terganggu. Penanaman bibit yang terlalu banyak pada satu lubang tanaman menyebabkan terjadinya persaingan, baik pada unsur hara, cahaya serta ruang tumbuh sehingga anakan yang terbentuk tidak maksimal (Armansyah, Sutoyo dan Angraini, 2009).

Beberapa kelemahan yang dimiliki dari sistem Tapin menurut Pitojo (2003) diantaranya adalah : (a) pada saat bibit dicabut dari tempat persemaian maka bibit akan mengalami kerusakan pada sistem perakarannya. Keadaan ini akan mempengaruhi proses adaptasi tanaman, dimana bibit padi tersebut akan berhenti mengabsorbsi air, sedangkan dilain pihak proses transpirasinya tetap berlangsung. Bila keadaan ini berlangsung dalam interval waktu yang agak panjang maka bibit akan mengalami kekurangan air, terjadi penurunan tekanan turgor dari guard cell (sel penjaga), stomata tertutup, difusi CO2 tertekan dan pada akhirnya terhentinya proses fotosintesis. (b). Pada saat bibit tanaman padi. dicabut dari persemaian akan terjadi pelukaan pada sistem perakarannya, hal ini mempengaruhi daya tahan tanaman dimana luka yang ada akan menyebabkan bibit penyakit dapat masuk ke dalam tanaman. (c) Pada saat bibit tanaman padi dicabut dari persemaian dan dipindahkan ke sawah, akan terjadi proses stagnasi dimana pertumbuhan bibit tanaman akan terhenti sementara sampai dapat beradaptasi dengan lingkungan barunya, (d) sistem budidaya melalui persemaian lebih cocok untuk musim penghujan karena proses transpirasi (penguapan) dapat ditekan lajunya sehingga bibit padi dapat terhindar dari proses kelayuan dan terakhir (e) sistem budidaya melalui persemaian akan membutuhkan tenaga kerja lebih banyak dimana untuk luasan satu hektar akan membutuhkan kurang lebih 10 orang tenaga kerja transplanting dan membutuhkan waktu lebih kurang 8 jam.

Pertambahan tinggi tanaman bukan hanya ditentukan oleh faktor genetik tapi juga oleh faktor lingkungan. Kemampuan suatu genotip untuk memunculkan karakternya tergantung dari kondisi lingkungan pertumbuhan, apabila kondisi lingkungan tidak menguntungkan, maka sifat yang dibawanya tidak dapat dimunculkan secara maksimal (Lestari, 2012)

\section{Komponen Hasil Tanaman Padi}

Panjang malai, gabah berisi, gabah hampa dan jumlah biji per malai

Tabel 3. Rata-rata Panjang malai, Gabah Berisi, Gabah Hampa dan Jumlah Total Permalai

\begin{tabular}{|c|c|c|c|c|c|}
\hline Kode & Perlakuan & $\begin{array}{c}\text { Panjang } \\
\text { malai }(\mathrm{cm})\end{array}$ & $\begin{array}{c}\text { Gabah isi per } \\
\text { malai (butir) }\end{array}$ & $\begin{array}{c}\text { Gabah hampa } \\
\text { per malai } \\
\text { (butir) }\end{array}$ & $\begin{array}{c}\text { Gabah total per } \\
\text { malai (butir) }\end{array}$ \\
\hline SRI & $\begin{array}{l}\text { System Rice } \\
\text { Intensification }\end{array}$ & $26.11 a b$ & $162.00 \mathrm{bc}$ & $14.00 \mathrm{a}$ & $176.00 \mathrm{a}$ \\
\hline $\mathrm{Hz}$ & Hazton & $25.62 a b$ & 135.67 a & $5.67 \quad a$ & $141.33 \mathrm{a}$ \\
\hline $\mathrm{Tg}$ & Tegel & $28.70 \mathrm{c}$ & $168.33 \mathrm{c}$ & $13.67 \mathrm{a}$ & $182.00 \mathrm{a}$ \\
\hline $\mathrm{Hb}$ & Hambur & $26.72 \mathrm{~b}$ & $143.33 \mathrm{ab}$ & $23.33 \mathrm{a}$ & 166.67 a \\
\hline $\mathrm{Tb}$ & Tabela & $24.84 \mathrm{a}$ & $137.33 \mathrm{a}$ & $19.33 \mathrm{a}$ & 156.67 a \\
\hline $\operatorname{Lg}$ & Legowo & $27.11 \mathrm{bc}$ & $163.33 \mathrm{c}$ & $9.33 \mathrm{a}$ & $172.67 \mathrm{a}$ \\
\hline KK & & 0.18 & 0.83 & 1.21 & 0.81 \\
\hline
\end{tabular}

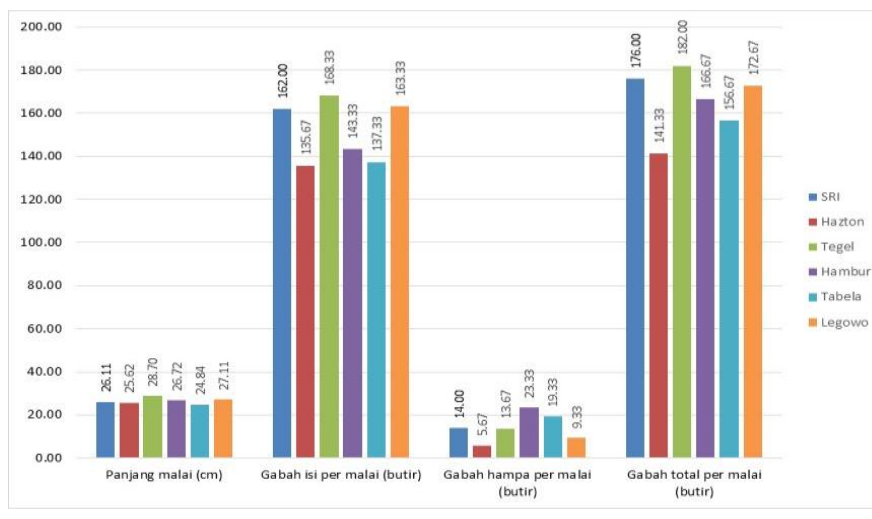

Gambar 4. Grafik jumlah Panjang malai, gabah berisi, hampa dan jumlah total gabah permalai

Pada Tabel 4 dan Gambar 5. menunjukkan bahwa tanaman padi dapat tumbuh optimal jika ditanam dengan menggunakan sistem tanam legowo 2:1 karena lebih banyak lorong yang kosong yang berarti lebih banyak tanaman pinggir. Prinsip dari sistem tanam jajar legowo adalah pemberian kondisi pada setiap barisan padi untuk mengalami pengaruh sebagai tanaman barisan pinggir. Umumnya, tanaman pinggir menunjukkan pertumbuhan yang lebih baik karena kurangnya persaingan tanaman antarbarisan.

Menurut Giamerti dan Yursak (2011), padi yang ditanam secara beraturan dalam bentuk tegel hasil tanaman bagian luar lebih tinggi 1,5-2 kali dibandingkan hasil tanaman yang berada di bagian dalam.Dengan diterapkannya sistem tanam legowo yang menambah kemungkinan barisan tanaman untuk mengalami efek tanaman pinggir (border effect), sinar matahari dapat dimanfaatkan lebih banyak untuk proses fotosintesis, intensitas cahaya yang cukup selama pertumbuhan dan perkembangan tanaman padi, sangat 
berpengaruh terhadap proses pembentukan komponenkomponen hasil dan pengisian gabah. Efektivitas penyerapan hara lebih tinggi sehingga tanaman padi bisa tumbuh dengan optimal pada kondisi lahan tersebut Pada lahan yang lebih terbuka karena adanya lorong pada baris tanaman, serangan hama dapat berkurang dan dengan terciptanya kelembapan lebih rendah, perkembangan penyakit juga dapat berkurang.

Jarak tanam dan orientasi tanaman di lapang mempengaruhi enam proses penting, yaitu (1) Penangkapan radiasi surya oleh individu tanaman, terutama daun untuk fotosintesis, (2) Efektivitas penyerapan hara oleh akar tanaman, (3) Kebutuhan air tanaman, (4) Sirkulasi Udara $\mathrm{CO} 2$ untuk fotosintesis dan $\mathrm{O} 2$ untuk hasil fotosintesis, (5) Ketersediaan ruang yang menentukan populasi gulma, (6) Iklim mikro (kelempabapn dan suhu udara) di bawah kanopi, yang berpengaruh terhadap perkembangan Organisme Penganggu Tanaman (OPT) (Makarim dan IKhwani, 2012) semuanya ini berpengaruh terhadap kualitas pertumbuhan individu rumpun tanaman padi.

Berat 1000 butir, hasil per petak dan Hasil per hektar Tabel 5. Rata-rata Jumlah Berat 1000 Butir (g) Hasil Tanaman Per Petak (Kg) dan Per Hektar (Ton)

\begin{tabular}{clccc}
\hline Kode & Perlakuan & $\begin{array}{c}\text { Berat 1000 } \\
\text { Butir (g) }\end{array}$ & $\begin{array}{c}\text { Hasil Per petak } \\
(\mathrm{Kg})\end{array}$ & $\begin{array}{c}\text { Hasil GKG } \\
\text { (tonha) }\end{array}$ \\
\hline SRI & $\begin{array}{l}\text { System Rice } \\
\text { Intensification }\end{array}$ & $23.33 \mathrm{a}$ & $7.63 \mathrm{bc}$ & $11.67 \mathrm{ab}$ \\
$\mathrm{Hz}$ & Hazton & $26.33 \mathrm{a}$ & $7.93 \mathrm{bc}$ & $12.08 \mathrm{bc}$ \\
$\mathrm{Tg}$ & Tegel & $26.33 \mathrm{a}$ & $8.13 \mathrm{bc}$ & $12.60 \mathrm{c}$ \\
$\mathrm{Hb}$ & Hambur & $24.33 \mathrm{a}$ & $5.57 \mathrm{a}$ & $8.56 \mathrm{a}$ \\
$\mathrm{Tb}$ & Tabela & $25.00 \mathrm{a}$ & $6.57 \mathrm{ab}$ & $9.91 \mathrm{ab}$ \\
$\mathrm{Lg}$ & Legowo & $25.67 \mathrm{a}$ & $8.57 \mathrm{c}$ & $13.07 \mathrm{c}$ \\
\hline $\mathrm{KK}$ & & 0.17 & 0.29 & 0.36 \\
\hline
\end{tabular}

Keterangan: Angka-angka yang diikuti oleh huruf yang sama pada kolom yang sama menunjukkan berbeda tidak nyata pada uji Duncan taraf $5 \%$.

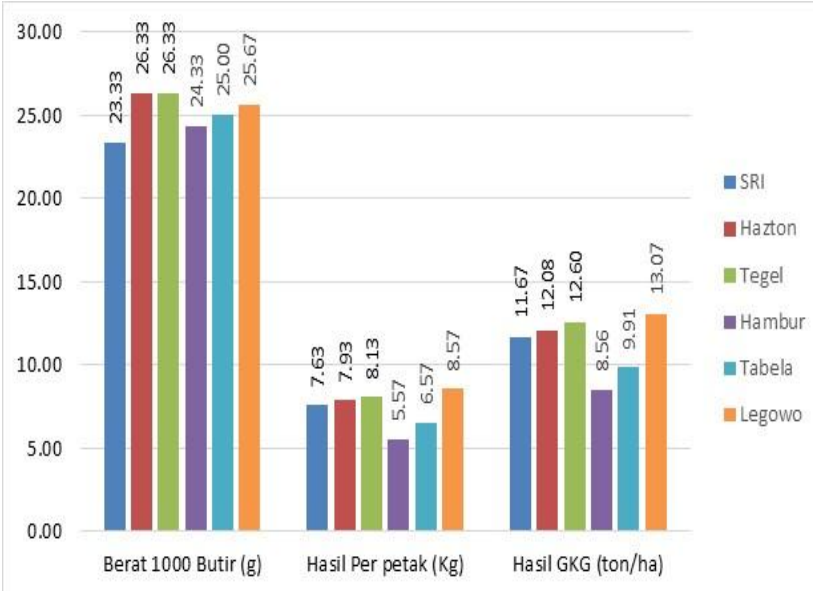

Gambar 5. Grafik rata-rata berat 1000 butir, hasil per petak dan hasil per hektar
Pada Tabel 5 dan Gambar 5. terlihat bahwa perlakuan sistem tanam tidak berbeda nyata terhadap berat gabah 1000 butir hal tersebut dikarenakan varietas yang digunakan untuk semua sistem tanam adalah sama dimana salah satu faktor yang menentukan berat bobot 1000 butir adalah genetik dari varietas. Menurut Jumin (2002) bahwa organorgan yang menghasilkan mempunyai batas genetika dalam hal ukuran maksimumnya, jadi tidak mungkin laju pertumbuhan organ tanaman tersebut dapat ditingkatkan dengan meningkatkan secara berlebihan jaringan pensuplai asimilat.

\section{Kesimpulan}

Berdasarkan hasil pengamatan, analisa, dan pembahasan dapat disimpulkan bahwa pertumbuhan dan hasil tanaman padi dipengaruhi oleh banyak faktor, salah satunya adalah sistem tanam. Sistem tanam tabela menunjukkan rata-rata tinggi tanaman terbaik pada umur 45 HST dan 60 HST. Padi yang ditanam menggunakan legowo (13.07 ton/ha), tegel (12.60 ton/ha) dan hazton (12.08 ton/ha) menghasilkan produksi lebih tinggi dibanding sistem SRI (11.67 ton/ha), tabela (9.91 ton/ha) dan hambur (8.56 ton/ha)

\section{Daftar Pustaka}

Armansyah, S., \& Anggraini, R. (2009). Pengaruh periode pengenangan air terhadap pembentukan jumlah anakan pada tanaman padi (oryza sativa) dengan metode SRI (The System of Rice Intensification). Laporan Penelitian Dosen Muda. Fakultas Pertanian Universitas Andalas. Padang.

Badan Pusat Statistik. 2018. Data Pokok Polewali Mandar 2017. Polewali Mandar

Badan Penelitian dan Pengembangan Pertanian. 2013. Sistem Tanam Legowo. Kementerian Pertanian.

Barkelaar, D. 2001. Sistem Intensifikasi Padi (The System of Rice Intensification) : Sedikit dapat Memberi Lebih Banyak. Buletin ECHO Development Notes, Januari 2001. Terjemahan Oleh Indro Surono, Staf ELSPPAT. 2008. 1-6 hal.

Debby Eka. 2018. Cara Penanaman Padi. Diakses dari http://pemudatani.html pada tanggal 15 April 2018

Giamerti, Y. dan Yurzak Z. 2011. Keragaan Komponen Hasil dan Produktivitas Padi Sawah Varietas Inpari 13 pada berbagai Sistem Tanam. Balai Pengkajian Teknologi Pertanian Banten.1-8 hal.

Jumin, H. B. 2002. Agroekologi; Suatu Pendekatan Fisiologi. Raja Grafindo Persada. Jakarta. 154 hal.

Lestari, A. 2012. Uji Daya Hasil Beberapa Varietas Padi (Oryza Sativa L.) Dengan Metode SRI (The System of Rice Intensification) di Kota Solok.

Makarim, A.K dan Ikhwani. 2012. Teknik Ubinan, Pendugaan Produktivitas Padi menurut Jarak Tanam. Puslitbang Tanaman Pangan.Bogor. 44 hlm.

Pitojo, Setijo. 2003. Bertanam Padi Sawah Tabale. Jakarta: Penebar Swadaya.

Ridwan. 2000. Pengaruh Populasi Tanaman dan Pemupukan P Pada Padi Sawah Dengan Sistem Tanam Jajar Legowo. Dalam Prosiding Seminar Nasional 2000. Buku I. BPTP Sukarami. Padang. 62 hal. 
Rozen, N. 2009. Metode Penanaman Padi dengan Sistem SRI. 25 hal

Trias, 2014. Wujudkan Kemandirian Pangan. Kalimantan Barat.

Uphoff, N dan Fernandes. 2003. Sistem Intensifikasi Padi Terbesar Pesat. 31 Warren Hall, Comell University. 15-16 hal.

Usman. Z, Made. U, Adrianton. 2014. Pertumbuhan dan Hasil Tanaman Padi (Oryza sativa L.) pada Berbagai Umur Semai dengan Teknik Budidaya SRI (System of Rice Intensification). Agrotekbis 2(1):32-37. Palu. ISSN:2338-3011. 